\title{
The Pleasure of Aggressiveness Among Inmates in Preventive and Long- Term Detention
}

\author{
Michel Cabanac*,1, J. Martín Ramírez ${ }^{2}$, Luis Millana², Maria P. Toldos-Romero ${ }^{3}$ and \\ M.-Claude Bonniot-Cabanac ${ }^{1}$
}

${ }^{1}$ Université Laval, Québec City, ${ }^{2}$ Universidad Complutense Madrid, ${ }^{3}$ Universidad de Alcalá

\begin{abstract}
To a large degree, humans use pleasure (hedonicity) maximization to guide decision making, thereby optimizing their behaviour, as shown by research on either sensory or purely mental pleasure (e.g., pleasure from video-game playing or mathematical problem-solving). Our group has now found that pleasure determines decision making in situations of interpersonal aggression, i.e., people tend to behave aggressively in proportion to the resulting pleasure. In the present study, two groups of inmates in a Spanish prison were compared: those serving long sentences and those being held in preventive detention. All participants answered self-administered questionnaires that had been devised to examine how hedonicity influences decision making in the case of aggressive behaviour. The questionnaires described social conflict situations and offered four options ranging from a passive response to a highly aggressive response. Previous research showed similar results between inmates serving long terms and a non-delinquent population, even though the degree of hedonicity was higher in the inmates: increasingly aggressive behavior is increasingly pleasurable to the aggressor, but only up to a certain level.. In contrast, this paper shows that inmates in preventive detention did not rate any of the aggressive responses as pleasant. Such a difference was present in males only and may have been caused by a desire for social acceptance.
\end{abstract}

Keywords: Aggressiveness, hedonicity, emotion, prison inmates, decision making, social desirability.

\section{INTRODUCTION}

Our research group has studied aggression and violence in the general population of different cultures with a view to developing effective strategies of prevention for people who are at higher than average risk of being either perpetrators or victims. If these individuals have already demonstrated violent or seriously delinquent behaviour, the goal should be to lower the risk of recidivism. To this end, we should study more specific populations, such as psychiatric patients or prison inmates. Prevention of violence lies more with the criminal courts and the police than with the penal and corrective system, which traditionally becomes involved only after someone has already become violent (Devine, Gilligan, Miczek, Shaikh, \& Pfaff, 2004; Gilligan \& B. Lee, 2004). Even further upstream is research on prevention of violence.

The present study further explores the association between pleasure and aggression in delinquents, within the frame of a decision-making background. More specifically it was analyzed the paramount role of hedonicity (pleasure or displeasure) when delinquents make violence-related decisions, these people being more prone to violence than is the general population. Our model conceptualizes decisionmaking as mental prioritizing, requiring a common currency to rank motivations and assessing trade-offs, as postulated by McFarland and Sibly (McFarland \& Sibly, 1975) and by McNamara and Houston (McNamara \& Houston, 1986). Various motivations competing for access to this final

*Address correspondence to these authors at the Faculté de médecine, Université Laval, Québec, G1K 7P4, Canada:

E-mail: Michel.Cabanac@phs.ulaval.ca common path must be able to 'talk to one another' in order for the brain to rank their priority. A series of interdisciplinary studies allowed us to conclude that this common currency is the hedonic dimension of consciousness. In fact, our suggestion on the role of pleasure in decision-making indeed started within physiology (Cabanac, 1979). Then it was extended to other pleasures, such as money (Cabanac, 1986, 1995). Then to all motivations and decisions (Cabanac, 1992) as, eventually, maximization of pleasure was found in other realms of purely mental functioning optimization activity, such as enjoying poetry or video games, ethics, and mental calculus (Cabanac, et al. 19997, 2002) (Bonniot-Cabanac $\&$ Cabanac, (submitted)). The present piece of work explores the role of pleasure in decision making, adding a new dimension, the social one, to the general concept that maximizing pleasure is the way decisions are made. Within this context, aggression would give pleasure too, and vice versa, the goal of hedonic maximization may be a cause of aggression (Ramírez, Bonniot-Cabanac, \& Cabanac, 2005). A quite recent research in mice has shown that the brain responds to aggression in the same way as to sensory pleasures: for mice aggression is rewarding and dopamine's involved in that rewarding affect in the same areas of the brain that's rewarding for drugs, reproductive behavior, and anything that seems to be pleasant (Kennedy \& Couppis, 2008).

Previous research of our group documented for the first time that pleasure is a major factor in social situations related to interpersonal aggression in 'normal' population (Ramírez, Bonniot-Cabanac, \& Cabanac, 2003; Ramírez et al. 2005). Participants were asked to rate the pleasure or displeasure experienced in several minor conflicting social situations, and to decide how they would solve these situations. Several 
behavioral alternatives were given, from passive nonaggressive behavior to aggressive responses of rising intensities. People tended to make aggressive behavioral decisions as a function of the resulting pleasure: passive behavior and most aggressive behaviors were rated as unpleasant, but mild and moderate aggressive responses provided some pleasure to the aggressor in decisions. The moderate level of aggressiveness was the selected preference when participants were invited to make decisions. This relationship of pleasure with aggressiveness (Ramírez et al. 2003, 2005) has been recently confirmed by other researchers, showing that aggressive behavior (Haller \& Kruk, 2006; Helfritz \& Stanford, 2006; Meier, Robinson, \& Wilkowski, 2006; Slovic, 2007), and even cruelty (Nell, 2008), can be pleasurable. That research offers relevant evidence for the operation of hedonic considerations in decision-making about violence.

Hedonicity is still relatively unstudied with respect to prison inmates. In previous studies on a 'normal' population (Ramírez et al. 2003, 2005) and on inmates serving longterm for severe crimes (Ramírez, Millana, Toldos-Romero, Bonniot-Cabanac, \& Cabanac, 2007), both groups rated mildly aggressive behaviours as pleasant and selected them as their preferred responses to mild social conflicts. These similar results were congruent with our previous analysis on justification of aggression in different cultures suggesting a certain universal moral code, common to all humans (Ramírez, 1991, 1993, 2007b; Ramírez, Lagerspetz et al. 2001).

In the present study, two categories of prison inmates were compared for somewhat opportunistic reasons. Alongside the usual long-term inmates there was a small group in preventive detention who had not been sentenced yet. Our hypotheses was that inmates who had not been judged yet would most likely answer in a more socially desirable fashion than those inmmates already judged; i.e., they would show less degree of hedonicity related to aggression.

\section{METHODS}

\section{Participants}

Two groups of participants were recruited in a prison near Madrid. The first group contained 65 long-term inmates (53 men $37.7 \pm 1.1 \mathrm{yr} ; 12$ women $36.5 \pm 2.6 \mathrm{yr}$ ) who had already been sentenced and were serving for serious crimes. The second group contained 28 inmates in preventive detention (15 men, 35.0 $\pm 1.1 \mathrm{yr}$ and 13 women $36.0 \pm 2.4 \mathrm{yr}$ ). We excluded people who were illiterate in Spanish or psychiatrically disturbed, according to police records. The study was strictly anonymous and their participation was voluntary, receiving no compensation for it. Given the opportunistic nature of the study the sample sizes are relatively small and uneven.

\section{Questionnaires}

Participants were asked to answer three questionnaires that explored the pleasure/displeasure of aggressive behaviour, and their spontaneous level of aggressiveness.

\section{Psychophysics}

Questionnaire 1 (see sample in Appendix 1) presented fifteen minor social conflicts and explored the hedonistic valence they aroused. The items on Questionnaire 1 placed the participants in different conflict situations, describing an incident that could be seen as insulting, upsetting, or offensive. Each situation was presented four times, each time ending with a different behavioural response to the social conflict. Thus, there were sixty entries in total. The four possible behavioural responses were non-aggressive (passive, i.e., avoiding confrontation with the perpetrator), slightly aggressive (expressing displeasure or disapproval), mildly aggressive (complaining or reprimanding), or clearly aggressive. The order of presentation was randomized to remove this possible influence on the results. Half the participants received Questionnaire 1 with the items ordered from 1 to 60, and the other half from 60 to 1 . The response sheet had 60 parallel lines, as many as there were items on the questionnaire. Each line was $130 \mathrm{~mm}$ long, with zero hedonicity indicated in the middle and with pleasure and displeasure indicated on either side. Participants were instructed to rate the intensity of their pleasure or displeasure while reading each item: a situation followed by a response. They read the item, and then marked the line at their experienced magnitude of pleasure (to the right of the middle) or displeasure (to the left of the middle). We thus obtained an analog estimate of the participant's imagined hedonic (positive or negative) experience. The magnitude of aggressiveness was, of course, nonparametric as the four possible responses reflected personal judgment. A similar method has been repeatedly used in previous research (e.g., (Bonniot-Cabanac \& Cabanac, (submitted))(Ramírez et al. 2003, 2007)).

\section{Decision}

Questionnaire 2. To evaluate preference for a given aggressive response to a situation, we presented the same fifteen Questionnaire 1 situations, with each being followed by four possible behavioural responses (i.e., 15 entries). The test was thus a multiple-choice one where participants marked the responses they preferred. The order of the responses, and hence the magnitude of aggressiveness, was randomized for each of the 15 situations.

\section{Aggressiveness}

Questionnaire 3, known as the CAMA test, was originally designed by Lagerspetz and Westman (K. Lagerspetz \& Westman, 1980) and subsequently revised by Ramirez (Ramírez, 1985, 1991) (Ramírez \& Fujihara, 1997). The CAMA test estimates the participants' level of spontaneous aggressiveness by measuring how much they justify different types of aggressive acts in various situations. Although relatively novel, it has already been used in many countries: Finland (Lagerspetz \& Westman, 1980; Lagerspetz, Björkqvist, Björkqvist, \& Lundman, 1988), Great Britain (Benton, Kumari, \& Brain, 1982), Poland (Fraçzek, 1985; Fraçzek, Ramirez, \& Torchalska, 1985), Spain (Ramírez, 1985, 1991, 1993), Japan and the USA (Ramírez, Fujihara, VanGoozen, \& Santisteban, 2001)(Ramírez, Santisteban, Fujihara, \& VanGoozen, 2002), Iran (Musazadeh, 1999), India (Sunni, see (Ramírez, 2007a), and South Africa (Ramírez, Lagerspetz et al. 2001). We included it in this study (see Appendix 2), having previously described some of its psychometric properties and validated features.

\section{RESULTS}

\section{Questionnaire 1 (Hedonicity)}

Passive responses and the most aggressive responses were rated unpleasant by both groups. There was, however, a 


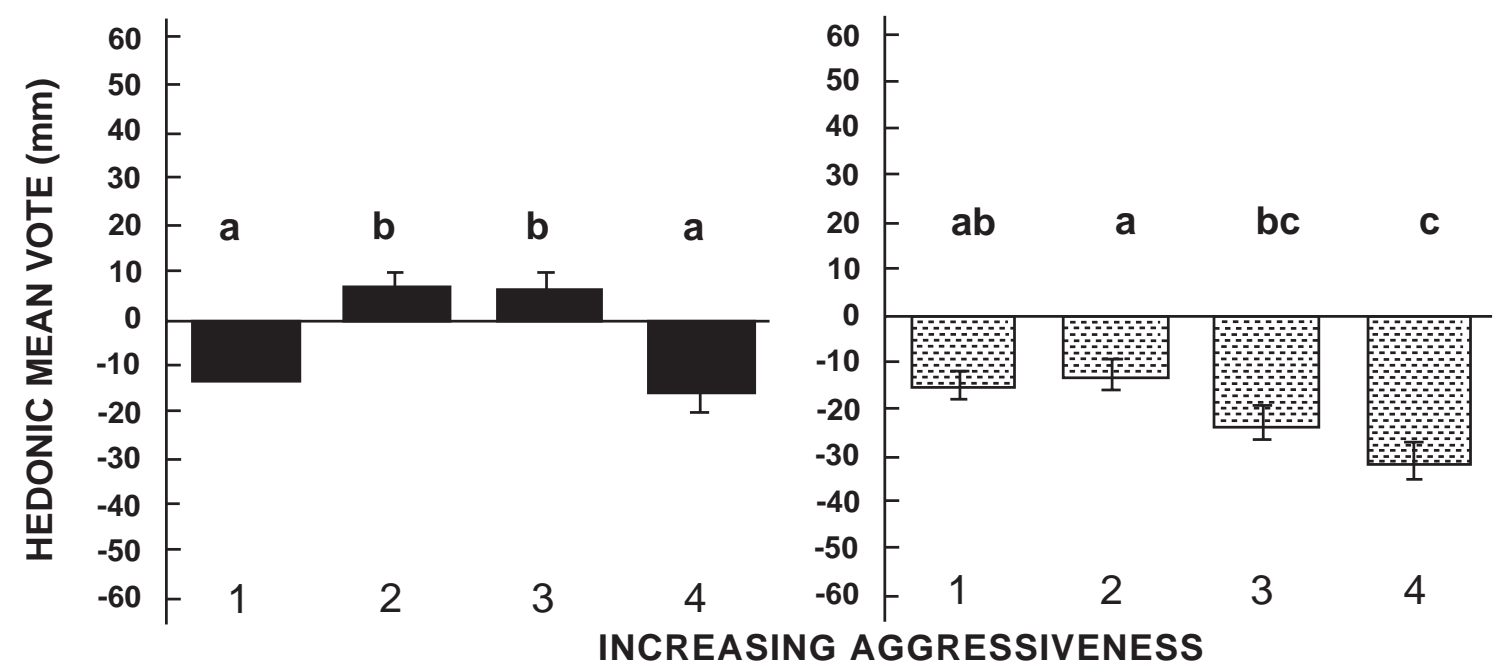

Fig. (1). Mean results from Questionnaire 1: mean hedonicity ratings of the various items. On the x-axis, columns 1, 2, 3, and 4 represent increasingly aggressive responses. Left: long-term inmates; same letter, a or b, indicates a non-significant difference (ANOVA, F-Value 9.62, $\mathrm{p}<0.0001)$. Right: inmates in preventive detention, i.e., held in prison pending trial and awaiting minor sentences; same letter, $a$, $b$, or $c$ indicates a non-significant difference (ANOVA, F-Value 5.26, $\mathrm{p}=0.002$ ).

difference in their ratings of slightly and mildly aggressive responses (Fig. 1): whereas long-term inmates described both responses as pleasant, inmates in preventive detention described them as unpleasant. Ratings also differed by sex: whereas men rated all responses as unpleasant, women followed a bell curve of hedonicity vs. aggressiveness, similar to the one shown by long-term inmates and by a 'normal' population in previous studies) (Fig. 2 presents the Questionnaire 1 results separately for men and women).

\section{Questionnaire 2 (Decision making)}

Both groups selected responses with an aggressiveness magnitude ca. 2 (see Table 1). Their choices were the ones that yielded the most pleasure among long-term inmates and the least displeasure among inmates in preventive detention

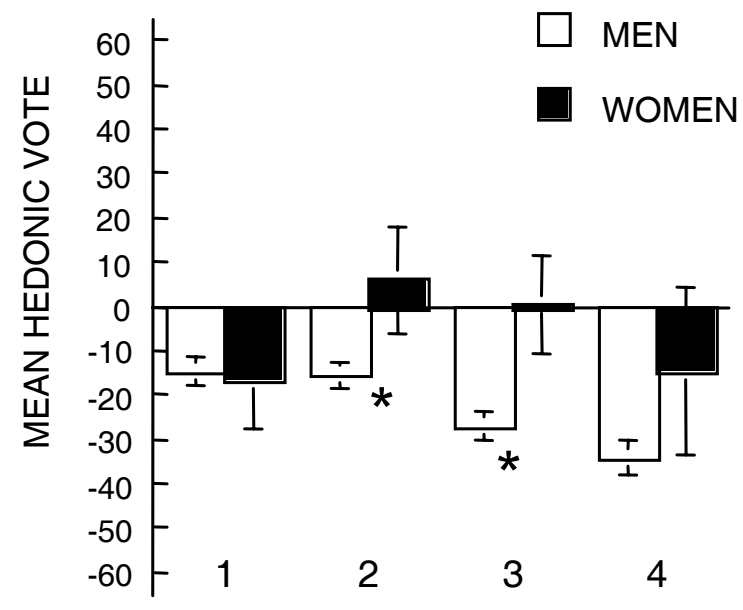

\section{INCREASING AGGRESSIVENESS AggreAGGRESSIVENESS}

Fig. (2). Mean results by sex for inmates in preventive detention from Questionnaire 1 (presented Fig. 1). The results from longterm inmates are not shown because none of the sex differences reached statistical significance. Student's $t$ tests: ${ }^{*} \mathrm{p}<0.02$. (as can be seen on Fig. 1). Thus, although long-term inmates considered responses with aggressiveness intensity 3 to be pleasant, they did not select them on Questionnaire 2. All inmates selected responses they had rated highest for pleasure, but they chose responses with an aggressiveness magnitude of 2, although they had rated magnitude 3 responses almost equally pleasant.

Sex differences in decision making were exhibited only by inmates in preventive detention: the men chose slightly more aggressive responses than did the women (2.1 vs. 1.7) (ANOVA sex* group yielded $\mathrm{F}=3.7, \mathrm{p}=0.026$ ). No significant sex differences were exhibited by long-term inmates.

Individual hedonic ratings were compared with individual behavioural preference to see if the two correlated. There was a significant correlation for long-term inmates $(n=65, Z$ value $=-2.199, \mathrm{p}=0.027$ ) but not for inmates in preventive detention $(n=28, Z$ value $=-1.071, p=0.28)$.

\section{Questionnaire 3 (Justification of aggression)}

With long-term inmates, justification of aggression, as measured by CAMA, correlated positively with the mean selected response on Questionnaire 2 (F-value 5.686, $\mathrm{p}=0.021$ ). Such a correlation suggests that the more aggressive participants tended to select more aggressive responses on Questionnaire 2 (Fig. 3). Such a correlation was not found with inmates in preventive detention, though.

There were no sex differences in the CAMA test results among either long-term inmates or inmates in preventive detention.

\section{DISCUSSION}

When hedonicity is plotted as a function of rising aggressiveness it follows a bell curve in long-term criminal population: pleasure is related to slight and moderate aggressive responses while passive or highly aggressive responses are rated as unpleasurable. This bell curve is similar to the one previously obtained from university populations in Quebec City (Ramírez, 2003) and Madrid (Paradis, Ramirez, \& Ca- 
Table 1. Mean responses \pm se selected on Questionnaire 3. Aggressive responses may range from 1 (passive behaviour) to 4 (clearly aggressive behaviour). The mean pleasure or displeasure of the responses is computed from the Questionnaire 1 ratings

\begin{tabular}{|c|c|c|}
\hline & \multicolumn{2}{|c|}{ MEAN AGGRESSIVENESS RATING OF PLEASURE } \\
\hline \hline LONG-TERM DETENTION & $2.0 \pm 0.1$ & $28.0 \pm 3.6$ \\
\hline PREVENTIVE DETENTION & $1.9 \pm 0.1$ & $-11.4 \pm 3.1$ \\
\hline
\end{tabular}

banac, 2007).This is also the case for female inmates in preventive detention. On the contrary, for male preventive inmates all their ratings were negative: they felt the four aggressiveness intensities as unpleasurable.

Long-term inmates rated positively responses with aggressiveness intensity 3 on Questionnaire 1, even when they did not select them on Questionnaire 2. This suggests that their decisions might be influenced by different factors, such as their own agreeableness (Meier et al. 2006), heredity (Marler, Trainor, \& Davis, 2005), previous learning of the consequences of aggression (Carnagey \& Anderson, 2006), or impulsiveness (Ramírez et al. 2005). There was a significant correlation between aggressiveness (CAMA test) and selected response among long-term inmates (F-value 7.249, $\mathrm{p}<0.01$ ), as in our previous studies (Millana, Cabanac, Toldos-Romero, Bonniot-Cabanac, \& Ramírez, 2006; Ramírez, 1993), but no such correlation was observed among inmates in preventive detention. All ratings were lower among inmates in preventive detention than among longterm inmates, as well as among the university participants in our previous studies (Ramírez et al. 2003, 2005). Their response was consistent on all three questionnaires: they described all responses as unpleasant on Questionnaire 1; their CAMA did not correlate with their choices, an indication of low aggressiveness; and their choices on Questionnaire 2 were similar to those of participants from the other group.

The results from inmates in preventive detention may reflect social desirability or self-presentational biases. Be-

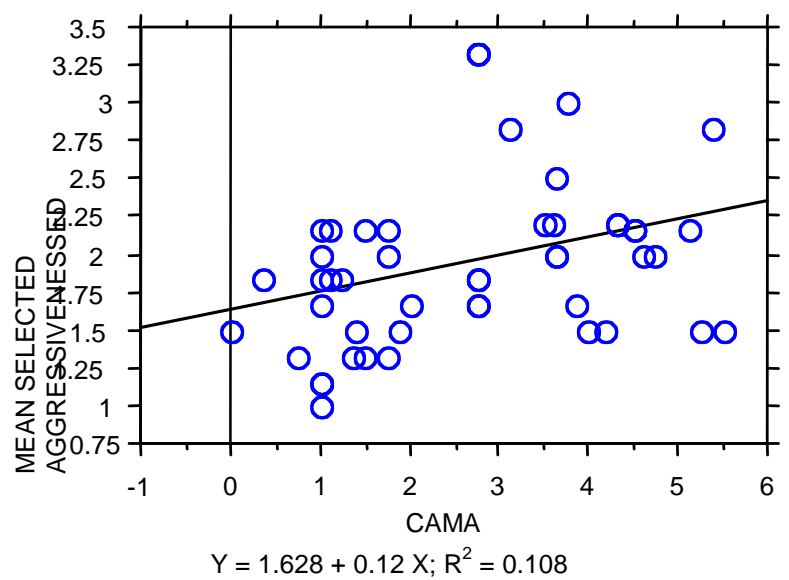

Long-term detention
F-value 5.686
$\mathrm{p}=0.021$ cause they had not been judged yet, they would most likely answer in a socially desirable fashion despite the anonymity of the study, as part of a strategy to get out earlier. Chances of early release may be reduced if one admits to engaging in and deriving pleasure from aggressive activities. If such social desirability and self-presentational biases did influence the responses, self-report would have to be treated more cautiously in this kind of study to ensure accuracy. Although assured of anonymity, the participants may still have been reluctant to disclose feelings about pleasurable experiences or justification of aggression for fear of reprisals from prison authorities. This reluctance could have biased their decisionmaking, making them less approving of aggression in comparison to a 'normal' population.. The social desirability hypothesis is supported by the non-significant correlations between the responses and the ratings of responses among inmates in preventive detention. Their selected responses probably were inconsistent with what they really felt, reflecting instead a desire to please the researchers.

In summary, violence is a multi-faceted phenomenon resulting from complex interactions among a variety of biological, psychological, and social variables (Ramírez \& Andreu, 2003; Slovic, 2007). If aggressiveness seems to depend largely on the social environment before adulthood, as has been shown by many researchers (Boivin \& Vitaro, 1995; Kerr, 1994; Lansford et al. 2002; Poulin \& Boivin, 2000), one could also expect that aggressiveness would become more pleasurable in a prison environment among inmates serving long sentences for severe crimes, as the present study

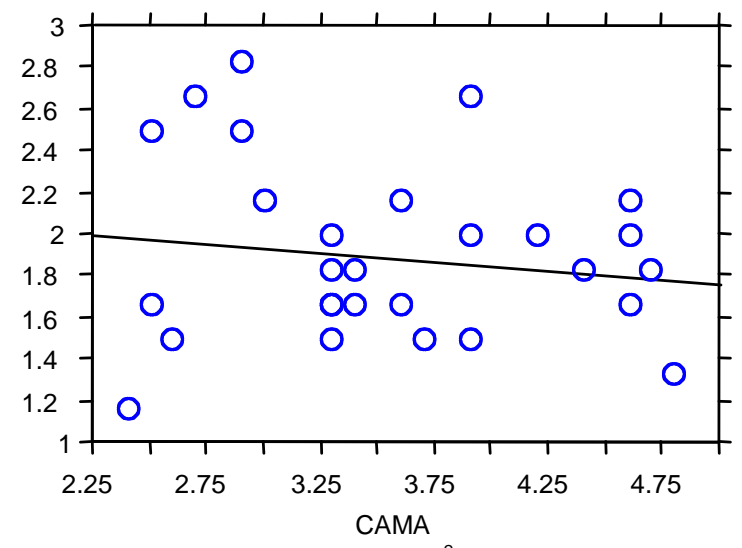

$Y=2.21-0.009 X ; R^{2}=0.22$

Preventive detention F-value 0.575 $\mathrm{p}=0.455$

Fig. (3). Correlation between Questionnaire 3 results (CAMA aggressiveness test) and mean aggressiveness of responses selected by Questionnaire 2 participants. 
shows. The more violent the inmate, the greater would be the net immediate reinforcement. The benefits from violent behaviour would include such immediate ones as intrinsic satisfaction from the violent act itself and such long-term ones as a possibly exciting lifestyle (O'Donoghue \& Rabin, 2000; Rachlin, 2004). This may also be related to a more aggressive disposition underlying unlawful behaviours.

Pleasure is motivation in human general decision making (Cabanac, 1992; Dieckmann, Dickert, Peters, \& Slovic, 2004; Johnston, 2003; Mellers, 2000; Slovic, Finucane, Peters, \& MacGregor, 2002). Hedonicity is both a goal and information about progress toward this goal (Schnall, Clore, \& Ryan, 2006). The above results, even if they only show correlations but not the causation, confirm that pleasure maximization may be a fundamental motivation for human aggressive behaviour too, As. it has quite recently being found in animals, the brain responds to aggression in the same way as other pleasures (Kennedy \& Couppis, 2008). It is therefore paramount to incorporate this concept into models of human motivation and choice (DeMartino, Kumaran, Seymour, \& Dolan, 2006). In the absence of contextual cues or situational constraints, choices follow a pleasuremaximizing principle (Fischer, 2004; Mellers, Schwartz, \& Ritov, 1999; Vastfjall \& Garling, 2006).

\section{REFERENCES}

Benton, D., Kumari, N., \& Brain, P. F. (1982). Mild hypoglycaemia and questionnaire measures of aggression. Biological Psychology, 14, 129-135.

Boivin, M., \& Vitaro, F. (1995). The impact of peer relationship on aggression in childhood: inhibition through coercion or promotion through peer support. In McCord, J. (Ed.), Coecion and Punishment in Long-Term Perspectives (pp. 183-197). New York: Cambridge University Press.

Bonniot-Cabanac, M. C., \& Cabanac, M. Pleasure in decision making situations : Politics and gambling. J. Risk Res. (in press).

Cabanac, M. (1971). Physiological role of pleasure. Science, 173, 11031107.

Cabanac, M. (1979). Sensory pleasure. Quarterly Review of Biology, 54, 1 29.

Cabanac, M. (1986). Money versus pain: experimental study of a conflict in humans. Journal of the Experimental Analysis of Behavior, 46, 3744.

Cabanac, M. (1992). Pleasure: the common currency. Journal of Theoretical Biology, 155, 173-200.

Cabanac, M. (1995). Palatability vs. money: experimental study of a conflict of motivations. Appetite, 25, 43-49.

Cabanac, M., Guillaume, J., Balasko, M., \& Fleury, A. (2002). Pleasure in decision-making situations.Psychiatry.

Cabanac, M., Pouliot, C., \& Everett, J. (1997). Pleasure as a sign of efficacy of mental activity. European Psychologist, 2, 226-234.

Carnagey, N. L., \& Anderson, C. A. (2006). The effects of reward and punishment in violent video games on aggressive affect, cognition, and behavior. Psychological Science, 16, 882-889.

DeMartino, B., Kumaran, D., B. Seymour, \& Dolan, R. J. (2006). Frames, biases, and rational decision-making in the human brain. Science, 313, 684-687.

Devine, J., Gilligan, J., Miczek, K. A., Shaikh, R., \& Pfaff, D. (2004). Youth violence : scientific approaches to prevention. Annals of the New York Academy of Science, 1036.

Dieckmann, N., Dickert, S., Peters, E., \& Slovic, P. (2004). Positive affect mediates the impact of buyer/seller status on likelihood estimations and prices in the endowment effect. Paper presented at the 16th Annual Convention of the American Psychological Society, Chicago.

Fischer, A. R. H. (2004). User Adaptation in User-System Interaction. Technische Universiteit, Eindhoven.

Fraçzek, A. (1985). Moral approval of aggressive acts: a Polish-Finish comparative study. Journal of Cross-Cultural Psychology, 16, 41-54.
Fraçzek, A., Ramirez, J. M., \& Torchalska, B. (1985). Attitudes toward interpersonal aggression. In F. LeMoli (Ed.), Multidisciplinary Approach to Conflict and Appeasement in Animals and Man (pp. 182). Parma: Instituto di Zoologia.

Gilligan, J., \& B. Lee. (2004). The psychopharmacologic treatment of violent youth. Annals of the New York Academy of Science, 1036, 356381 .

Haller, J., \& Kruk, M. R. (2006). Normal and abnormal aggression: human disorders and novel laboratory models. Neuroscience \& Biobehavioral Reviews, 30, 292-303.

Helfritz, L. E., \& Stanford, M. S. (2006). Personality and psychopathology in an impulsive aggressive college sample. Aggressive Behavior, 32, 28-37.

Johnston, V. S. (2003). The origin and function of pleasure. Cognition and Emotion, 17, 167-179.

Kennedy, C. H., \& Couppis, M. H. (2008). The rewarding effect of aggression is reduced by nucleus accumbens dopamine receptor antagonism in mice Psychopharmacology, in press.

Kerr, J. H. (1994). Understanding soccer hooliganism. Philadelphia: Open University Press.

Lagerspetz, K., \& Westman, M. (1980). Moral approval of aggressive acts. A preliminary investigation. Aggressive Behavior, 6, 119-130.

Lagerspetz, K. M. J., Björkqvist, K., Björkqvist, H., \& Lundman, H. (1988). Moral approval of aggression and sex role identity in officer trainees, conscientious objectors to military service, and in a female reference group. Aggressive Behavior, 14, 303-313.

Lansford, J. E., Dodge, K. A., Pettit, G. S., Bates, J. E., Crozier, J., \& Kaplow, J. (2002). A 12-year prospective study of the long-term effects of early child physical maltreatment on psychological, behavioral, and academic problems in adolescence. Archives of Pediatrics \& Adolescent Medicine, 156, 824-830.

Marler, C., Trainor, B. C., \& Davis, E. (2005). Paternal behavior and offspring aggression. Current Directions in Psychological Science, 14, 163-166.

McFarland, D. J., \& Sibly, R. M. (1975). The behavioural final common path. Philosophical Transactions of the Royal Society, 270, $265-$ 293.

McNamara, J. M., \& Houston, A. I. (1986). The common currency for behavioural decisions. American Naturalist, 127, 358-378.

Meier, B. P., Robinson, M. D., \& Wilkowski, B. M. (2006). Turning the other cheek. Agreeableness and the regulation of aggression-related primes. Psychological Science, 17, 136-142.

Mellers, B., Schwartz, A., \& Ritov, I. (1999). Predicting choices from emotions. Journal of Experimental Psychology, G: 128, 332-345.

Mellers, B. A. (2000). Choice and relative pleasure consequences. Psychological Bulletin, 126, 910-924.

Millana, L., Cabanac, M., Toldos-Romero, M. P., Bonniot-Cabanac, M.-C., \& Ramírez, J. M. (2006). Placer asociado con la conducta agresiva en una muestra de reclusos españoles en prisión preventiva. Psicopatología Clínica, Legaly Forense, 5, 119-132.

Musazadeh, Z. (1999). Agresión y su justificación: un estudio comparado de studiantes iranies y españoles. Universidad Complutense, Madrid.

Nell, V. (2006). Cruelty's rewards: The gratifications of perpetrators and spectators. Behavioral and Brain Sciences, 29, 224-257.

O'Donoghue, T., \& Rabin, M. (2000). The economics of immediate gratification. Journal of Behavioral Decision Making, 13, 233-250.

Paradis, S., Ramirez, J. M., \& Cabanac, M. (2007) Emotional and instrumental aggressiveness and body weight loss. European Journal of Psychologist, http://www.ejof.org/archives/2007/11/emotional_ and_i.html

Poulin, F., \& Boivin, M. (2000). The role of proactive and reactive aggression in the formation and development of boys' friendships. Developmental Psychology, 36, 233-240.

Rachlin, H. (2004). The behavioral economics of violence. Annals of the New York Academy of Science, 1036, 325-335.

Ramírez, J. M. (1985). Attitudes toward aggression in four Spanish regions. In: F. L. Moli (Ed.), Multidisciplinary approaches to conflict and appeassement in animals and man (pp. 63). Parma: INstituto di Zoologia.

Ramírez, J. M. (1991). Similarities in attitudes toward interpersonal aggression in Finland, Poland, and Spain. Journal of Social Psychology, 131, 737-739.

Ramírez, J. M. (1993). Acceptability of aggression in four Spanish regions and a comparison with other European countries. Aggressive Behavior, 19, 185-197. 
Ramírez, J. M. (2003). Human Aggression: A Multifaceted Phenomenon. Madrid: Centreur.

Ramírez, J. M. (2007a). Justification of aggression in several Asian and European countries with different religious and cultural backgrounds. International Journal of Behavioral Development 31, 915.

Ramírez, J. M. (2007b). Television y violencia. Revista Latinoamericana de Psicologia, 39, 327-349.

Ramírez, J. M., \& Andreu, J. M. (2003). Types of aggression. International Review of Social Psychology, 16, 125-141.

Ramírez, J. M., Bonniot-Cabanac, M.-C., \& Cabanac, M. (2003). Impulsive aggression and pleasure. In: J. M. Ramírez (Ed.), Human Aggression (pp. 449-472). Madrid: Centreur.

Ramírez, J. M., Bonniot-Cabanac, M.-C., \& Cabanac, M. (2005). Can Aggression Provide Pleasure? European Psychologist, 10, 136-145.

Ramírez, J. M., \& Fujihara, T. (1997). Cross-cultural study of attitudes toward interpersonal aggression (in Japanese, with a summary in English). Kwansei Gakuin Sociology Studies, 78, 97-103.

Ramírez, J. M., Fujihara, T., VanGoozen, S., \& Santisteban, C. (2001). Anger proneness in Japanese and Spanish students. In: J. M. Ramírez \& D. S. Richarson (Eds.), Cross-Cultural Approaches to Aggression and Reconciliation. Huntington, N.Y.: Nova Science Publishers, Inc.

Ramírez, J. M., Lagerspetz, K. M., Fraczek, A., Fujihara, T., Theron, W. H., Musazadeh, Z., et al. (2001). Moral approval of aggressive acts by urban students: a cross-national study on four continents. In J. M. Ramírez \& D. S. Richarson (Eds.), Cross-Cultural Approaches to Aggression and Reconciliation (pp. 61-67). Huntington, N.Y.: Nova Science Publishers, Inc.

Ramírez, J. M., Millana, L., Toldos-Romero, M. P., Bonniot-Cabanac, M.C., \& Cabanac, M. (2007). The pleasure of being aggressive in incarcerated criminals. submitted.

Ramírez, J. M., Santisteban, C., Fujihara, T., \& VanGoozen, S. (2002). Differences between experience of anger and readiness to angry action (a study of Japanese and Spanish students). Agressive behavior. 27, 313-322.

Schnall, S., Clore, G. L., \& Ryan, K. (2006). Embodied affect as information: performance versus hedonic orientations. Abstract I-129 APS Convention New York, 133.

Slovic, P. (2007). If I look at the mass I will never act: Psychic numbing and genocide. Judgment and Decision Making, 2, 79-95.

Slovic, P., Finucane, M., Peters, E., \& MacGregor, D. G. (2002). The affect heuristic. In T. Gilovich, D. Griffin \& D. Kahneman (Eds.), Heuristics and Biases: The Psychology of Intuitive Judgment (pp. 397420). New York: Cambridge University Press.

Vastfjall, D., \& Garling, T. (2006). Preference for negative emotions. Emotion, 6, 326-329.

Received: December 14, 2007

Revised: April 09, 2008

Accepted: April 09, 2008

(C) Cabanac et al.; Licensee Bentham Open.

This is an open access article licensed under the terms of the Creative Commons Attribution Non-Commercial License (http://creativecommons.org/licenses/by-nc/3.0/) which permits unrestricted, non-commercial use, distribution and reproduction in any medium, provided the work is properly cited. 


\section{APPENDIX 1}

\section{Samples of Questionnaires 1 and 2.}

\section{Questionnaire 1}

The respondents are asked four times to imagine being in each of 15 situations. A specific action tendency that is tailored to the situation under consideration is suggested in response to each question. The respondents have to indicate how intense pleasure or displeasure they would feel when experiencing each specific action.

You are in a parking lot waiting for a free space. Just when you find a free place, another driver arrives and takes it in your presence.

Look for another space

You are in a movie theatre and behind you there are two persons who are talking loudly. They disturb you

Move to another seat

You are on a train. In your compartment, arrives a mother with a noisy child.

Move to another compartment

You are watching television in a dormitory. A group of people enter and, without saying anything, they change the channel.

Leave without saying anything

You are waiting for some friends and decide to buy some nice fruits as a dessert. When you arrive home, you realize that half of them are rotten.

Forget about the fruits. Offer your guests something different for dessert

You are on a crowded bus. An old, tired lady arrives and asks a young person to give up his seat. The young person refuses.

Go to the back of the bus to avoid any conflict

You are in a parking lot waiting for a free space. Just when you find a free place, another driver arrives and takes it in your presence.

Honk your horn to show your displeasure

\section{Questionnaire 2}

The respondents are asked to imagine being in each of 15 situations and to indicate what they would feel inclined to do. Each vignette offers four possible behavioral responses of different intensity levels, that are tailored to the situation under consideration.

You are in a parking lot waiting for a free space. Just when you find a free place, another driver arrives and takes it in your presence.

Look for another space.

Honk your horn to show your displeasure.

Get out of your car and argue with the person.

Get out or your car and kick the person's car with your foot.

You are in a movie theatre and behind you there are two persons who are talking loudly. They disturb you.

Move to another seat.

Make an exasperating sound, indicating your displeasure.

Ask them to stop talking

Find the usher and tell him to stop the people from talking.

You are on a train. In your compartment, arrives a mother with a noisy child.

Move to another compartment.

Ask the child to behave.

Tell, with an impatient voice, the motherto control her child.

Chastise and slap the child.

You are watching television in a dormitory. A group of people enter and, without saying anything, they change the channel.

Leave without saying anything 


\section{APPENDIX 2}

\section{CAMA}

Aggression has proven to be a serious problem in society today. In this research we try to investigate how people relate to different types of aggressive acts. It is only natural that we all get angry in certain situations. Sometimes we would even feel it wrong not to get angry.

Below we present six situations in which some aggressive act might occur. We mention eight possible aggressive acts. We ask you to estimate if in your opinion each act is usually justified or not in each situation.

\section{List of situations}

1. IN SELF-DEFENSE

2. TO PROTECT ANOTHER PERSON

3. WHEN COMMUNICATION BREAKS DOWN

4. WHEN ANGRY

5. TO PROTECT ONE'S PROPERTY

6. AS A PUNISHMENT

\section{List of aggressive acts}

1. TO BE IRONICAL

2. TO THREATEN

3. TO STOP SOMEBODY FROM DOING SOMETHING

4. TO USE TORTURE

5. TO SHOUT ANGRILY

6. TO HIT ANOTHER PERSON

7. TO GET FURIOUS

8. TO KILL ANOTHER PERSON 